\title{
Banking fragility and liquidity creation: options as a substitute for deposits
}

\section{Wolf Wagner}

Received: 21 May 2007 / Accepted: 17 January 2008 / Published online: 8 February 2008

(C) The Author(s) 2008

\begin{abstract}
Diamond and Rajan(J Finance 55:2431-2465, 2000; Am Econ Rev Papers Proc 91:422-425, 2001a; Carnegie-Rochester Conf Series Public Policy 54:37-71, 2001b; J Pol Econ 109:287-327, 2001c) have shown in a series of papers that is precisely the fragility of their capital structure which allows banks to create liquidity. This is because the threat of runs by depositors forces bankers to extract full repayment on otherwise illiquid assets. This result has important implications for financial regulation, such as for capital requirements and deposit insurance. This note shows that put options held by bank owners dominate deposit financing in that they also discipline bankers but do not give rise to inefficient runs. Fragility is thus not necessary for liquidity creation in the Diamond-Rajan framework.
\end{abstract}

Keywords Banking fragility $\cdot$ Liquidity creation $\cdot$ Put options

\section{JEL Classification $\quad \mathrm{G} 21 \cdot \mathrm{G} 28$}

\section{Introduction}

Banks finance themselves to a large extent through deposits. This is costly, as it exposes them to runs, and raises the question of why banks choose such a fragile capital structure. In a series of papers, Diamond and Rajan (2000, 2001a,b,c) have provided an explanation for the prevalent use of deposit financing.

Their argument is based on the hold-up problem which banks suffer from. During the lending process, bank managers acquire valuable knowledge about banks' assets.

This paper has substantially benefitted from the comments and suggestions of an anonymous referee.

W. Wagner $(\bowtie)$

TILEC, CentER and Department of Economics, Tilburg University, Tilburg, The Netherlands e-mail:wagner@uvt.nl 
By threatening to quit and to withdraw their knowledge, they can renegotiate their compensation with the banks' owners and secure themselves a part of the value added by the bank. As a result, banks cannot pledge the full value of their assets, implying that their assets are illiquid.

Diamond and Rajan show that deposits financing can address this hold-up problem since bank managers cannot renegotiate with depositors. Any attempt to do so would immediately trigger a run, as depositors must fear a reduction in their repayments. Thus, the threat of a run permits to extract higher payments from bank managers and to raise more funds against banks' assets. Therefore, it is precisely the fragility of their capital structure which allows banks to create liquidity. However, deposit financing also runs the risk of inefficient liquidations when bad luck leads to asset returns that are insufficient to repay depositors in full. In fact, full extraction of bank managers' rents through deposits inevitably causes runs when asset returns are low [Lemma 1 in Diamond and Rajan (2000)].

In this note, I show that a bank which is financed without deposits can extracts rents in full without causing inefficient liquidations. In this I assume that bank owners may buy put options on their own bank. Put options allow owners to be compensated when a liquidation of their bank leads to low pay-offs. As a result, they improve owners' outside option in negotiations with bank managers by making the alternative of replacing the manager and liquidating the bank less costly. This in turn reduces managerial rents. ${ }^{1}$

Such put options are feasible in the contractual environment considered by Diamond and Rajan. They also appear feasible in practice since options are traded on many of the largest banks (e.g., Bartram et al. 2005). Compared to deposits, options have the advantage that their use can be easily adjusted to the return on banks' assets, which avoids inefficient liquidations. Thus, a fragile capital structure is not a necessary prerequisite for efficient liquidity creation.

To demonstrate this argument, I use a simplified version of Diamond and Rajan (2000) (DR hereafter). An economy consists of an entrepreneur, a banker (a relationship lender) and investors (arms-length financiers). All agents are risk neutral and the discount rate is zero. The economy lasts for one period. At date 1, the banker raises funds from investors and lends $1 \$$ to the entrepreneur to carry out a project. At date 2 , the project's state is revealed. When the project is in the high state (occurring with probability $q^{H}$ ), the banker can collect $X^{H}$ from the entrepreneur, while if the project is in the low state (occurring with probability $1-q^{H}$ ) the banker can collect $X^{L}$ (with $\left.X^{L}<X^{H}\right)$. The project's pay-off $X^{s}(s=L, H)$ is observable but not contractible. Investors, who do not have the banker's specific ability, can only extract $\beta X^{s}$ (with $\beta<1$ ) from the project by liquidating it.

At date 2 a hold-up problem arises because the banker can threaten to withdraw his ability. To see this, suppose that the bank is fully financed by capital. Capital's pay-off from the project without the banker (that is from liquidating it) is $\beta X^{s}$. Hence, the banker can, by threatening to quit, negotiate down any initial claim capital may have

1 Effectively, the put options are used to toughen the capital structure, which could also be achieved by using multiple lenders (e.g., Berglöf and Thadden 1994; Bolton and Scharfstein 1996; Dewatripont and Tirole 1994) or credit protection (Arping 2005). 
to $\beta X^{s}$, assuming that he has full bargaining power. ${ }^{2}$ As a result, the bank can only raise an amount of $\beta E[X]$ at date 1 (where $E[X]=q^{H} X^{H}+\left(1-q^{H}\right) X^{L}$ ), although the present value of the project is $E[X]$. Hence, the project is illiquid in the sense that it cannot fetch its full value.

This setup corresponds to the single-period model in DR, with the main difference being that DR also model a hold-up problem between the banker and the entrepreneur. The latter is not essential for our purpose because solving the renegotiation problem between capital and the banker also solves the hold-up between the banker and the entrepreneur. This is because whenever capital can force the banker to pay the full cash-flows on the project, the banker has to force the entrepreneur to do likewise.

DR show that banks can create liquidity (i.e., raise more funds at date 1) by issuing deposits. This is because deposit financing leads to a collective action problem among depositors: if the banker tries to negotiate down depositors' claims, it becomes individually optimal for each depositor to run on the bank. As this leads to the liquidation of the bank, the banker would be left without rents. Thus, the banker always honours depositors' claims, if possible. Still, as DR show, the bank cannot pledge the present value of the project $E[X]$ at date 1 (Lemma 1 in DR). This would require the amount of deposits to be set to $X^{H}$, in order to extract rents in full in the high state. But this inevitably causes runs in the low state as $X^{L}<X^{H}$, leading to liquidation and the loss of the banker's ability. ${ }^{3}$

Suppose now that capital can buy at date 2 (before renegotiation with the banker takes place) a put option from a third party (the 'option writer'). ${ }^{4}$ The put option gives capital the right to a cash payment equal to the difference between its strike price and the bank's liquidation value whenever the bank is liquidated. Such an option is feasible in the DR-framework, as the bank's value after liquidation needs to be verifiable in order to distribute the proceeds among capital owners and depositors. ${ }^{5}$

The option writer is risk neutral and behaves competitively. He is assumed not to enter into any renegotiations to prevent liquidation of the bank. This seems plausible since option writers are typically large financial institutions which make frequent interactions in financial markets. Reputational concerns are therefore likely to deter them from renegotiating. Moreover, there are important practical impediments to renegotiation. Rather than having a single option writer, there are in practice likely to be a wide dispersion of option writers on a bank. Free-riding problems will make it unattractive

\footnotetext{
2 In DR the bargaining power is split between the banker and investors, but this is not essential.

3 Somewhat similar to options on the bank pursued here, DR suggest as an avenue for future research insurance against bad outcomes of the project, which may help to avoid bank runs by depositors (p. 2459 in DR). In contrast to our use of options, such insurance would require that states are verifiable, reducing the renegotiation problem from the outset.

4 In a monitoring framework, Chiesa (2005) shows that securitized loans that include a put-option can induce bank monitoring. These options allow investors to sell back the loans to the bank at a pre-specified price. Since the bank is effectively the protection seller in her framework, they cannot solve the renegotiation problem analyzed here.

5 With some complications our arguments also hold for standard put options on bank's equity (note that their tradeability only requires the verifiability of the payouts to equity but not the verifiability of the project's cash flows itself). What becomes essential then is that the option specifies cash-settlement in order to avoid that the claims are just reassigned to the protection seller.
} 
for an individual option writer to renegotiate in order to avoid liquidation. ${ }^{6}$ In addition, a coordination of their actions will be difficult to achieve due to the anonymity and decentralized nature of derivatives markets.

Consider a bank financed without deposits. Suppose that capital buys at date 2 (before renegotiation takes place) one put option with strike price $P^{H}=X^{H}$ when the high state has occurred and with strike price $P^{L}=X^{L}$ when the low state has occurred. ${ }^{7}$ Consider next renegotiation by the banker and suppose that he offers to pay out $r^{s}\left(r^{s} \leq X^{s}\right)$ to capital. Capital's pay-off from rejecting the offer, liquidating the project and exercising the option is $\beta X^{s}+\left(P^{s}-\beta X^{s}\right)=X^{s}$, as the put option fully insures the liquidation value. If the offer is accepted, capital obtains the offered amount $r^{s}$. Hence, capital will reject the offer whenever $r^{s}<X^{s}$ and accept when $r^{s}=X^{s}$.

Since his rents are zero if capital rejects and the project is liquidated, the banker has to offer $r^{s}=X^{s}$, that is the full cash-flow. As a result, there is no liquidation in equilibrium. The option is then never exercised and its price is zero. Thus, it is indeed optimal for capital to acquire such an option at date 2 as it allows to extract the project's payoffs without incurring any costs. Note that in fact the mere existence of options may be sufficient to deter renegotiation, as the banker will be aware of the possibility for capital to buy an option if he attempts to renegotiate.

\section{Discussion}

Costly options. We have assumed that the option writer behaves competitively. In practice, however, option are written by large financial institutions, which may exercise some bargaining power. Capital may then not be able to purchase the option at its fair price, but, say, at the fair price plus $\delta(\delta>0)$, which is the rent transfer to the option writer. ${ }^{8}$ Capital will then only purchase the option when the rents which can be extracted from the banker by using the option, $(1-\beta) X^{s}$, exceed the costs of the option, $\delta$. It follows that, as long as the option seller cannot fully capture the banker's rents (that is, if he has not the full bargaining power), it remains optimal for capital to buy the option. And even if the option seller has the full bargaining power, the option would still be used in equilibrium because otherwise the option writer would not obtain any rents (the option writer would then allow capital to extract some small rents in order to make it preferable for capital to buy the option).

\footnotetext{
6 Dispersed option writers have a similar effect on the renegotiation problem as the multiplicity of lenders in Berglöf and Thadden (1994), Bolton and Scharfstein (1996), and Dewatripont and Tirole (1994). A difference is though, as shown below, that protection is more flexible than debt since its purchase can be separated from the financing stage and hence can be adjusted to new information.

7 Thus, the option's characteristics are chosen conditional on the project's state. Options which are bought before the state of the project is revealed still dominate deposits in the sense that all allocations which can be generated by deposits can also be implemented by options and, additionally, there are parameter constellations where options can extract higher payments from the bank manager without making liquidation of the bank more likely (calculations available on request).

8 Note that the option costs are here in absolute terms. If they were proportional to the fair price of option (i.e., a relative markup over the fair price), they would not affect our analysis since the equilibrium fair price of the option is zero, as shown above.
} 
Multiple borrowers. DR, who also model a renegotiation problem between the banker and the borrower, have shown that in the presence of multiple borrowers a new problem can arise: when the total offered repayment by all borrowers is not sufficient to meet the bank's current obligations, the banker has to decide which borrowers to liquidate. This issue does not materialize here since the option forces the banker to always extract full repayment from each borrower. Thus, all borrowers have to offer full repayment and no borrower ever gets liquidated.

Deposit insurance. Note that put options also dominate a standard deposit insurance scheme. The reason is as follows. Deposit insurance obviously avoids inefficient runs by depositors. However, it also removes the disciplining effect of deposits (as argued by DR). A put option, by contrast, can achieve both: it achieves discipline but can also avoid inefficient runs.

Optimal length and timing of option contracts. In our model there is only one shock and one renegotiation date. Options are bought after the shock has arrived, but before renegotiation takes place. In a richer setting, bank assets may not be subject to a single shock only and renegotiation may take at several points in time. Options should then be bought in intervals: Just before every renegotiation opportunity capital buys an option that just spans the renegotiation date. The reason for this is that capital wants to avoid buying long-term options. This is because the gains from options can only be reaped in full if their strike price is set close to value of the bank's assets. If an option has a longer duration, there will be more uncertainty about the value of the bank's assets at the date the option expires. This is suboptimal because when the value of bank assets is above the strike price, the banker can keep some rent, while if it is below it becomes optimal (ex-post) for capital to exercise the option, causing inefficient liquidation of the bank.

Open Access This article is distributed under the terms of the Creative Commons Attribution Noncommercial License which permits any noncommercial use, distribution, and reproduction in any medium, provided the original author(s) and source are credited.

\section{References}

Arping, S.: Credit protection and lending relationships. Mimeo. University of Amsterdam (2005)

Bartram, S.M., Brown, G.W., Hund, J.E.: Estimating systemic risk in the international financial system. Working paper no. 2005-12, FDIC Center for Financial Research (2005)

Berglöf, E., Thadden, E.V.: Short-term versus long-term interests: capital structure with multiple investors. Q J Econ 109, 1055-1084 (1994)

Bolton, P., Scharfstein, D.: Optimal debt structure and the number of creditors. J Pol Econ 104, 1-25 (1996) Chiesa, G.: Risk transfer, lending capacity and real investment activity. Mimeo. University of Bologna (2005)

Dewatripont, M., Tirole, J.: A theory of debt and equity: diversity of securities and manager-shareholder congruence. Q J Econ 109, 1027-1054 (1994)

Diamond, D., Rajan, R.: A theory of bank capital. J Financ 55, 2431-2465 (2000)

Diamond, D., Rajan, R.: Banks and liquidity. Am Econ Rev Papers Proc 91, 422-425 (2001a)

Diamond, D., Rajan, R.: Banks, short-term debt and financial crises: theory, policy implications and applications. Carnegie-Rochester Conf Series Public Policy 54, 37-71 (2001b)

Diamond, D., Rajan, R.: Liquidity risk, liquidity creation and financial fragility: a theory of banking. J Pol Econ 109, 287-327 (2001c) 